PEMBELAJAR: Jurnal Ilmu Pendidikan, Keguruan, dan Pembelajaran

Volume 5 Nomor 1 April 2021

e-ISSN: 2549-9114 dan p-ISSN: 2549-9203

(Received: September-2020; Reviewed: Februari-2021; Published: April 2021)

DOI: https://doi.org/10.26858/pembelajar.v5i1.15169

\title{
Integrasi Penilaian Formatif Pada Pembelajaran Microteaching di Prodi Pendidikan Matematika Universitas Qomaruddin
}

\author{
Illah Winiati Triyana ${ }^{1}$, Junaidah Wildani ${ }^{2}$ \\ Prodi Pendidikan Matematika, Universitas Qomaruddin, Indonesia \\ Corresponding e-mail: illahwiniati@uqgresik.com
}

\begin{abstract}
Abstrak: Penelitian ini bertujuan untuk mengintegrasikan penilaian formatif pada matakuliah microteaching dan mengetahui respon mahasiswa calon guru terhadap integrasi penilaian formatif pada pembelajaran microteaching. Untuk mencapai tujuan tersebut, digunakan desain penelitian penelitian pra-experimental dengan jenis desain one-shot case study dengan subjek penelitian adalah mahasiswa semester VI Prodi Pendidikan Matematika Universitas Qomaruddin tahun akademik 2019-2020. Instrumen yang digunakan untuk mengumpulkan data dalam penelitian ini adalah angket respon mahasiswa yang sebelumnya telah dinyatakan valid oleh dua orang ahli. Hasil analisis data menunjukkan bahwa penilaian formatif terintegrasi dengan sangat baik pada pembelajaran microteaching dan $100 \%$ mahasiswa menyatakan setuju dan sangat setuju bahwa integrasi penilaian formatif pada pembelajaran bermanfaat dalam membantu mahasiswa mengetahui apa yang harus dilakukan untuk mencapai target pengetahuan dan keterampilan. 95,85\% mahasiswa menyatakan setuju atau sangat setuju bahwa integrasi penilaian formatif membantu mengetahui target kemampuan dan keterampilan yang harus dicapai. $93,75 \%$ mahasiswa setuju dan sangat setuju bahwa penilaian formatif dapat memotivasi mereka untuk meningkatkan pengetahuan dan keterampilan. 93,7\% mahasiswa menyatakan setuju dan sangat setuju bahwa penilaian formatif membantu mereka mengetahui tingkat pengetahuan dan keterampilannya. 91,68\% mahasiswa menyatakan setuju dan sangat setuju bahwa dengan integrasi penilaian formatif, mereka merasa menjadi pebelajar yang mandiri
\end{abstract}

Kata Kunci: penilaian formatif, microteaching, pendidikan

Abstract: This study aims to integrate formative assessment into microteaching course and to know
students' response toward the integration of formative assessment into microteaching
course. To achieve these goals, the researcher applied pra-experimental research design
in the type of one-shot case study with the subject of this study is students from
mathematics education study program in semester six $2019-2020$ academic year. The
instrument used to collect the data for is student questioner which has been validated by
two experts. The result of data analysis shows that formative assessment has been very
well integrated to microteaching learning and $100 \%$ students agreed and very agreed that
formative assessment helps them in knowing what to do to achieve their knowledge and
skill target. $95,85 \%$ students agreed and very agreed that formative assessment helps them
in knowing their knowledge and skill target. $93,75 \%$ students agreed and very agreed that
through the integration of formative assessment, they are motivated to improve their
knowledge and skill. $93,7 \%$ students agreed and very agreed that formative assessment
helps them knowing what they know and what they skilled. $91,68 \%$ students agreed and
very agreed that through integration of formative assessment they become independent
learners.

Keywords: formative assessment, microteaching, education

(1) (9) (C2021 -Ini adalah artikel dengan akses terbuka dibawah licenci CC BY-NC-4.0

(https://creativecommons.org/licenses/by-nc/4.0/) by penulis. 


\section{PENDAHULUAN}

Mata kuliah microteaching merupakan mata kuliah yang umum diberikan di program pendidikan calon guru, baik itu calon guru tingkat dasar, atau menengah. Microteaching sendiri didefinisikan sebagai pembelajaran yang bertujuan untuk melatih keterampilan mengajar yang dilakukan dengan penyederhanaan setiap komponen pembelajaran seperti waktu, materi, jumlah siswa, keterampilan dasar mengajar yang dilatihkan, penggunaan metode dan media pembelajaran dan lain-lain (Sukirman, 2012). Definisi tersebut mengimplikasikan bahwa tujuan pembelajaran microteaching di institusiinstitusi pendidikan calon guru adalah untuk membekali mahasiswa calon guru seperangkat keterampilan yang dibutuhkan untuk melaksanakan pembelajaran di kelas.

Di prodi Pendidikan Matematika Universitas Qomaruddin sendiri, mata kuliah microteaching diselenggarakan dengan tujuan membentuk dan mengembangkan kompetensi dasar mengajar mahasiswa calon guru matematika sebagai bekal praktik mengajar di sekolah atau Lembaga Pendidikan lainnya. Setelah memperoleh mata kuliah ini, mahasiswa calon guru matematika diharapkan dapat merancang dan menyelenggarakan praktik mengajar matematika yang berkualitas secara mandiri dan sungguhsungguh. Untuk itu, pembelajaran microteaching dirancang sedemikian hingga pengalaman belajar mahasiswa mampu menjadikan mereka pebelajar yang mandiri.

Untuk mencetak mahasiswa menjadi pebelajar yang mandiri, tentunya dosen perlu menerapkan strategi-strategi pembelajaran tertentu. Salah satu strategi pembelajaran yang dinilai dapat melatih kemandirian mahasiswa adalah dengan mengintegrasikan penilaian formatif dalam pembelajaran. Yang dimaksud dengan penilaian formatif disini adalah serangkaian proses penilaian dimana hasil penilaian kinerja peserta didik digunakan untuk mendukung dan meningkatkan pembelajaran yang nantinya akan berdampak pada peningkatan kompetensi mereka (Sadler, 1989; Harlen, 2005).

Adapun prinsip-prinsip penilaian formatif menurut Glasson (2015) meliputi: 1) menggunakan penilaian kualitatif, 2) mengkomunikasikan standard/kriteria sukses pada siswa, 3) membuat penilaian dengan berbagai kriteria, dan 4) evaluasi pengalaman secara langsung. Lebih jauh lagi, Glasson (2015) mengidentifikasi strategi penilaian formatif yang meliputi: 1) mengkomunikasikan tujuan-tujuan pembelajaran dan kriteria sukses, 2) mengajukan pertanyaan-pertanyaan yang strategis, 3) memberikan umpan balik yang efektif, dan 4) mendorong peserta didik untuk melakukan penilaian pada diri sendiri. Berdasarkan penjelasan di atas, maka yang dimaksud dengan integrasi penilaian formatif pada pembelajaran disini adalah penerapan prinsip-prinsip dan strategi-strategi penilaian formatif dalam pembelajaran microteaching.

Black dan William (1998) menjelaskan bahwa untuk dapat menggunakan penilaian formatif sebagai alat pembelajaran, maka peserta didik harus mengetahui kompetensi yang ditargetkan, kompetensi mereka saat ini, dan bagaimana cara mencapai target kompetensi tersebut. Integrasi prinsip-prinsip dan strategistrategi penilaian formatif pada pembelajaran dipercaya dapat membantu peserta didik untuk mengetahui tiga hal yang disebutkan di atas. Lebih jauh lagi, Black dan Wiliam (1988) menjelaskan bahwa dalam penilaian formatif, guru (atau dosen) dapat menggunakan informasi yang diperoleh dari hasil penilaian kinerja peserta didik untuk memodifikasi praktik pembelajaran di kelas. Sedangkan peserta didik dapat menggunakan umpan balik yang diberikan oleh guru (dosen) untuk menyesuaikan pembelajaran mereka sendiri. Disini dapat dilihat bahwa dalam penilaian formatif, tidak hanya dosen yang dapat menginterpretasikan hasil penilaian, tetapi mahasiswa juga dapat secara aktif berpartisipasi dalam proses penilaian. Jadi disini peserta didik secara aktif berpartisipasi dalam penilaian mereka.

Dari penjelasan di atas, maka penelitian ini bertujuan untuk: 1) mengintegrasikan penilaian formatif pada matakuliah microteaching, 2) mengetahui respon mahasiswa calon guru terhadap integrasi penilaian formatif pada pembelajaran microteaching. Dari tujuan tersebut, maka dirumuskan pertanyaan penelitian sebagai beikut:

1) Bagaimana integrasi penilaian formatif pada pembelajaran microteaching di prodi Pendidikan matematika Universitas Qomaruddin?

2) Bagaimana respon mahasiswa prodi Pendidikan matematika terhadap integrasi penilaian formatif pada pembelajaran microteaching? 


\section{METODE}

\subsection{Desain dan Tahapan Penelitian}

Desain penelitian ini adalah penelitian praexperimental dengan jenis desain one-shot case study yaitu prosedur penelitian dimana sekelompok subjek diberi perlakukan tertentu kemudian dilakukan pengukuran terhadap variabel yang diinginkan (Arikunto, 2006). Pada penelitian ini, perlakuan yang dimaksud adalah integrasi penilaian formatif dalam pembelajaran microteaching matematika selama satu semester.

Terdapat tiga tahap utama dalam penelitian ini, yaitu; 1) persiapan: dimana peneliti merancang dan menyiapkan silabus dan rencana pembelajaran di kelas microteaching dengan fokus mengintegrasikan prinsip-prinsip penilaian formatif (Assessment for Learning) pada pembelajaran di kelas, 2) pelaksanaan: dimana peneliti melaksanakan pembelajaran yang terintegrasi dengan prinsip-prinsip penilaian formatif selama satu semester, dan 3) penilaian: yang dimaksud penilaian disini adalah, peneliti menilai respon mahasiswa calon guru terhadap pembelajaran yang telah terintegrasi dengan penilaian formatif yang dilaksanakan setelah UAS (Ujian Akhir Semester) yaitu pada bulan September 2020.

\subsection{Subjek Penelitian}

Subjek dari penelitian ini adalah mahasiswa semester VI prodi Pendidikan Matematika Universitas Qomaruddin tahun ajaran 20192020. Adapun penelitian dilaksanakan di Prodi Pendidikan Matematika, Fakultas Ilmu Keguruan dan Pendidikan, Universitas Qomaruddin di Gresik pada bulan Maret-Agustus 2020

\subsection{Instrumen Penelitian}

Untuk memperoleh data-data penelitian, maka peneliti menggunakan beberapa instrument penelitian yang meliputi silabus, Rencana Pelaksanaan Pembelajaran (RPP) dan angket respon.

Silabus dan RPP akan dirancang oleh peneliti dengan mengintegrasikan prinsip-prinsip penilaian untuk pembelajaran (Assessment for learning) ke dalam langkah-langkah pembelajaran di kelas. Silabus dan RPP ini berfungsi sebagai pemandu dosen untuk melaksanakan pembelajaran.

Angket respon digunakan untuk mengambil data respon mahasiswa terhadap pembelajaran yang telah terintegrasi dengan prinsip-prinsip penilaian formatif. Angket respon ini berisi 20 pernyataan dengan tujuh pernyataan diformulasikan untuk mengetahui apakah prinsip-prinsip penilaian formatif telah terintegrasi pada pembelajaran microteaching dan 13 pernyataan diformulasikan untuk mengetahui apakah mahasiswa merasakan kebermanfaatan integrasi penilaian formatif pada pembelajaran microteaching. Angket dilengkapi dengan pilihan respon yang meliputi tidak setuju (TS), kurang setuju (KS), setuju (S), dan sangat setuju (SS).

Sebelum angket respon tersebut digunakan untuk mengukur respons mahasiswa, angket divalidasi oleh dua validator terlebih dahulu. Validator angket dalam penelitian ini ada dua orang yang merupakan dosen yang sedang menempuh Pendidikan Doktor. Validator pertama memiliki bidang keahlian metodologi penelitian, sedangkan validator kedua memiliki bidang keahlian evaluasi pembelajaran. Kedua validator menyatakan bahwa angket respon layak digunakan pada penelitian ini.

\subsection{Analisis Data Penelitian}

Terdapat dua pertanyaan penelitian pada studi ini yaitu integrasi penilaian formatif pada pembelajaran microteaching di prodi Pendidikan matematika Universitas Qomaruddin dan bagaimana respon mahasiswa prodi Pendidikan matematika terhadap integrasi penilaian formatif pada pembelajaran microteaching.

Untuk menjawab pertanyaan pertama, data respon mahasiswa dianalisis dengan menggunakan Skala Likert dengan skor tiap respon sebagai berikut: tidak setuju $(\mathrm{TS})=1$, kurang setuju $(\mathrm{KS})=2$, setuju $(\mathrm{S})=3$, dan sangat setuju $(\mathrm{SS})=4$. Selanjutnya, jumlah skor tiap pernyataan dihitung dengan rumus

$$
J S=\frac{1 n_{1}+2 n_{2}+3 n_{3}+4 n_{4}}{4\left(n_{1}+n_{2}+n_{3}+n_{4}\right)} \times 100
$$

Dimana JS adalah Jumlah skor tiap pernyataan dan $n_{1}, n_{2}, n_{3}, n_{4}$ adalah banyak responden pada opsi tidak setuju, kurang setuju, setuju, dan sangat setuju secara berurutan.

Selain melihat skor tiap pernyataan, rata-rata skor juga dihitung untuk melihat keterlaksanaan penerapan prinsip-prinsip penilaian formatif secara umum.

Selanjutnya, skor dikelompokan kedalam kategori sebagai berikut

Tabel 1. Kriteria Skor

\begin{tabular}{cc}
\hline Interval Skor & Kategori \\
\hline $80<x \leq 100$ & Sangat Baik \\
$60<x \leq 80$ & Baik \\
$40<x \leq 60$ & Cukup
\end{tabular}




\begin{tabular}{cc}
$20<x \leq 40$ & Kurang Baik \\
$0 \leq x \leq 20$ & Sangat Kurang Baik \\
\hline
\end{tabular}

Untuk pertanyaan penelitian kedua, data respon mahasiswa dianalisis secara deskriptif dengan menghitung persentasi tiap respon untuk tiap pernyataan.

\section{HASIL DAN PEMBAHASAN}

\subsection{Integrasi Penilaian Formatif pada Pembelajaran Microteaching}

Integrasi penilaian formatif pada pembelajaran microteaching dilakukan dengan cara menerapkan prinsip-prinsip penilaian formatif pada pembelajaran microteaching. Keterlaksanaan penerapan ini dilihat dari respon mahasiswa yang diperoleh dari angket respon. Berikut adalah hasil angket respon mahasiswa terkait integrasi penilaian formatif pada pembelajaran microteaching matematika.

Tabel 2. Hasil Respon Mahasiswa Tentang Keterlaksanaan Integrasi Penilaian Formatif

\begin{tabular}{|c|c|c|}
\hline Pernyataan & Skor & Kategori \\
\hline $\begin{array}{l}\text { 1. Dosen } \\
\text { mengkomunikasikan } \\
\text { tujuan pembelajaran } \\
\text { dan indikator } \\
\text { ketercapaian tujuan } \\
\text { pembelajaran. }\end{array}$ & 84,38 & $\begin{array}{l}\text { Sangat } \\
\text { Baik }\end{array}$ \\
\hline $\begin{array}{l}\text { 2. Dosen } \\
\text { mengkomunikasikan } \\
\text { kriteria penilaian } \\
\text { untuk setiap tugas. }\end{array}$ & 81,25 & $\begin{array}{c}\text { Sangat } \\
\text { Baik }\end{array}$ \\
\hline $\begin{array}{l}\text { 3. Dosen melakukan } \\
\text { penilaian kualitatif } \\
\text { dalam pembelajaran. }\end{array}$ & 75 & Baik \\
\hline $\begin{array}{l}\text { 4. Dosen memberikan } \\
\text { evaluasi atau umpan } \\
\text { balik terhadap } \\
\text { kinerja/penampilan } \\
\text { mahasiswa }\end{array}$ & 86,46 & $\begin{array}{c}\text { Sangat } \\
\text { Baik }\end{array}$ \\
\hline 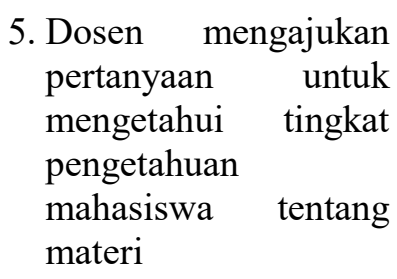 & 85,42 & $\begin{array}{c}\text { Sangat } \\
\text { Baik }\end{array}$ \\
\hline $\begin{array}{rr}\text { 6. Dosen mendorong } \\
\text { mahasiswa untuk } \\
\text { melakukan penilaian }\end{array}$ & 75 & Baik \\
\hline
\end{tabular}

pada diri sendiri (self-

assessment)

7. Dosen mendorong mahasiswa untuk memberikan umpan balik dan penilaian terhadap teman (peerassessment) terhadap kinerja dan penampilan

mahasiswa
Dari tabel di atas dapat diketahui bahwa setiap pernyatan masuk pada kategori sangat baik atau baik dan jika dirata-rata, diperoleh skor 81,69 yang masuk pada kategori sangat baik. Sehingga dapat disimpulkan bahwa penilaian formatif terintegrasi dengan sangat baik pada pembelajaran microteaching di prodi Pendidikan matematika, FKIP Universitas Qomaruddin.

\subsection{Respon Mahasiswa Terhadap Integrasi Penilaian Formatif pada Pembelajaran Microteaching}

Respon mahasiswa dianalisis untuk melihat apakah mahasiswa merasakan kebermanfaatan pembelajaran yang terintegrasi dengan prinsipprinsip penilaian formatif. Adapun kebermanfaatan tersebut dilihat dari lima aspek dimana tiap aspek terdiri dari 2-3 pernyataan. Untuk lebih jelasnya, hasil respon mahasiswa bisa dilihat pada tabel di bawah ini.

Tabel 3. Hasil Respon Mahasiswa tentang Kebermanfaatan Penilaian Formatif

\begin{tabular}{|c|c|c|c|c|}
\hline \multirow[t]{2}{*}{ Pernyataan } & \multicolumn{4}{|c|}{ Persentase Respon (\%) } \\
\hline & SS & $\mathbf{S}$ & KS & TS \\
\hline \multicolumn{5}{|c|}{$\begin{array}{l}\text { Aspek 1:Mahasiswa mengetahui tingkat } \\
\text { pengetahuan dan keterampilannya }\end{array}$} \\
\hline $\begin{array}{l}\text { Penilaian diri (self- } \\
\text { assessment) }\end{array}$ & 25 & 70,8 & & 4,2 \\
\hline $\begin{array}{l}\text { membantu saya } \\
\text { mengevaluasi }\end{array}$ & & & & \\
\hline pengetahuan & & & & \\
\hline keterampilan & & & & \\
\hline $\begin{array}{l}\text { dalam pengajaran } \\
\text { matematika }\end{array}$ & & & & \\
\hline $\begin{array}{l}\text { Pertanyaan- } \\
\text { pertanyaan yang } \\
\text { diajukan oleh dosen, } \\
\text { mampu membantu } \\
\text { sava }\end{array}$ & 33,3 & 58,3 & 8,3 & \\
\hline $\begin{array}{lr}\text { saya } & \text { untuk } \\
\text { mengevaluasi } & \text { kenerja }\end{array}$ & & & & \\
\hline
\end{tabular}


dan penampilan saya

secara mandiri

\begin{tabular}{|c|c|c|c|}
\hline $\mathrm{Ra}$ & 29.2 & 64.5 & 4.2 \\
\hline
\end{tabular}

Aspek 2: Mahasiswa mengetahui target pengetahuan dan keterampilan yang harus dicapai

\begin{tabular}{|c|c|c|}
\hline $\begin{array}{l}\text { Dengan } \\
\text { dikomunikasikannya } \\
\text { tujuan pembelajaran } \\
\text { berserta indikatornya, } \\
\text { saya dapat memahami } \\
\text { apa yang perlu saya } \\
\text { capai dalam } \\
\text { pembelajaran } \\
\text { microteaching }\end{array}$ & 33,3 & 66,7 \\
\hline \begin{tabular}{l}
\multicolumn{2}{c}{ Penilaian } \\
kualitatif membuat \\
saya lebih memahami \\
apa yang diharapkan \\
dosen terhadap \\
kinerja/penampilan \\
saya
\end{tabular} & 12,5 & $79,2 \quad 8,3$ \\
\hline Rata & 22,9 & $72,9 \quad 4,2$ \\
\hline
\end{tabular}

Aspek 3: Mahasiswa mengetahui apa yang harus dilakukan untuk mencapai target pengetahuan dan keterampilan

\begin{tabular}{|c|c|c|}
\hline $\begin{array}{l}\text { Dengan } \\
\text { dikomunikasikannya } \\
\text { kriteria penilaian } \\
\text { untuk setiap tugas, } \\
\text { saya dapat memahami } \\
\text { apa yang harus saya } \\
\text { lakukan untuk } \\
\text { mencapai } \\
\text { keberhasilan dalam } \\
\text { tugas tersebut }\end{array}$ & 33,3 & 66,7 \\
\hline $\begin{array}{l}\text { Umpan balik yang } \\
\text { diberikan dosen } \\
\text { membantu saya } \\
\text { memahami apa yang } \\
\text { harus saya lakukan } \\
\text { untuk meningkatkan } \\
\text { kinerja/penampilan } \\
\text { saya }\end{array}$ & 2,8 & 79,2 \\
\hline \begin{tabular}{l}
\multicolumn{2}{c}{ Dengan } \\
pertanyaan- \\
pertanyaan yang \\
diajukan oleh dosen, \\
saya dapat \\
mengetahui apa yang \\
harus saya lakukan \\
untuk memperbaiki \\
kinerja dan \\
penampilan saya
\end{tabular} & 33,3 & 66,7 \\
\hline Rata-rata & 29,1 & 70,9 \\
\hline
\end{tabular}

Aspek 4: Mahasiswa merasa menjadi pebelajar yang mandiri

\begin{tabular}{|c|c|c|c|}
\hline $\begin{array}{l}\text { Penilaian } \\
\text { kualitatif membuat } \\
\text { saya dapat } \\
\text { menginterpretasikan } \\
\text { hasil penilaian yang } \\
\text { saya peroleh }\end{array}$ & 20,8 & 70,8 & 8,3 \\
\hline \begin{tabular}{lr}
\multicolumn{1}{c}{ Saya } & merasa \\
dilibatkan secara aktif & \\
terhadap & proses \\
penilaian & dan \\
pembelajaran di kelas
\end{tabular} & 4,2 & 87,5 & 8,3 \\
\hline $\begin{array}{l}\text { Saya merasa } \\
\text { memegang kendali } \\
\text { atas pembelajaran } \\
\text { saya sendiri }\end{array}$ & 25 & 66,7 & 8,3 \\
\hline \begin{tabular}{lr}
\multicolumn{1}{c}{ Kegiatan- } \\
kegiatan pada \\
pembelajaran \\
microteaching \\
membantu saya \\
menjadi pebelajar \\
yang mandiri
\end{tabular} & 29,2 & 62,5 & 8,3 \\
\hline Rata-rata & 19,8 & 71,9 & 8,3 \\
\hline
\end{tabular}

Aspek 5: Mahasiswa merasa termotivasi untuk meningkatkan pengetahuan dan keterampilan

\begin{tabular}{|c|c|c|c|}
\hline $\begin{array}{l}\text { Dengan penilaian } \\
\text { diri (self-assesment) } \\
\text { saya lebih termotivasi } \\
\text { untuk memperbaiki } \\
\text { dan meningkatkan } \\
\text { kinerja dan } \\
\text { penampilan saya }\end{array}$ & 16,7 & 79,2 & 4,2 \\
\hline \begin{tabular}{lr}
\multicolumn{1}{r}{ Dengan umpan } \\
balik dari teman, saya \\
lebih termotivasi \\
untuk memperbaiki \\
dan meningkatkan \\
kinerja r dan \\
penampilan saya
\end{tabular} & 33,3 & 58,3 & 8,3 \\
\hline Rata-rata & 25 & 68,8 & 6,2 \\
\hline
\end{tabular}

Tabel diatas menunjukkan bahwa kebermanfaatan yang paling dirasakan mahasiswa dari integrasi penilaian formatif pada pembelajaran microteaching adalah pada aspek mahasiswa mengetahui apa yang harus dilakukan untuk mencapai target pengetahuan dan keterampilan dengan $100 \%$ mahasiswa menyatakan setuju dan sangat setuju bahwa kriteria penilaian untuk setiap tugas, umpan balik, dan pertanyaan-pertanyaan dari dosen dapat membantu mereka untuk lebih memahami langkah-langkah yang harus mereka ambil untuk mencapai target pengetahuan dan keterampilan mereka. 
Pada urutan kedua, manfaat yang paling dirasakan mahasiswa adalah pada aspek mahasiswa mengetahui target kemampuan dan keterampilan yang harus dicapai dengan 95,85\% mahasiswa menyatakan setuju atau sangat setuju bahwa dengan komunikasi tujuan pembelajaran beserta indikatornya dan penilaian kualitatif, mahasiswa dapat lebih memahami apa yang perlu dicapai dan apa yang diharapkan dosen dari terkait kinerja mereka dan penampilan mereka.

Selanjutnya, 93,75\% mahasiswa merasakan manfaat integrasi penilaian formatif pada aspek motivasi untuk meningkatkan pengetahuan dan keterampilan dimana mereka menyatakan setuju atau sangat setuju bahwa mereka merasa termotivasi untuk meningkatkan pengetahuan dan keterampilan melalui kegiatan penilaian diri sendiri (self-assessment) dan umpan balik dari teman sekelas.

Manfaat penilaian formatif pada aspek mengetahui tingkat pengetahuan dan keterampilannya juga dirasakan oleh sebagian besar mahasiswa dimana 93,7\% mahasiswa menyatakan setuju dan sangat setuju bahwa penilaian diri sendiri dan pertanyaan-pertanyaan yang diajukan oleh dosen mampu membantu mereka untuk mengevaluasi kinerja dan penampilan mereka dalam praktik pengajaran matematika sehingga mereka mengetahui tingkat pengetahuan dan keterampilan saat itu.

Manfaat penilaian formatif yang paling sedikit dirasakan mahasiswa adalah pada aspek mahasiswa merasa menjadi pebelajar yang mandiri dengan $91,7 \%$ mahasiswa menyatakan setuju dan sangat setuju bahwa mereka dapat menginterpretasikan hasil penilaian mereka, dilibatkan secara aktif dalam proses penilaian dan pembelajaran di kelas, memegang kendali atas pembelajaran mereka, dan menjadi pebelajar yang mandiri.

\subsection{Diskusi}

Jika dilihat secara keseluruhan, setiap aspek mendapat respon yang sangat positif dari mahasiswa dengan lebih dari 90\% mahasiswa menyatakan setuju dan sangat setuju pada setiap aspek. Namun perlu menjadi catatan juga bahwa ada beberapa mahasiswa yang kurang atau tidak merasakan manfaat integrasi penilaian formatif pada pembelajaran microteaching. Misalnya pada aspek mahasiswa merasa menjadi pebelajar yang mandiri, 8,3\% mahasiswa menyatakan kurang setuju dan tidak setuju pada tiap pernyataan pada aspek ini.
Hal ini menyiratkan bahwa ada hal yang harus dibenahi dalam integrasi penilaian formatif pada pembelajaran microteaching sehingga seluruh mahasiswa dapat merasakan manfaatnya. Dalam hal ini, perlu dikaji lagi mengapa mahasiswa-mahasiswa tersebut kurang atau tidak merasakan manfaat integrasi penilaian formatif pada pembelajaran microteaching yang dapat dilakukan dalam penelitian lanjutan dari penelitian ini.

\section{KESIMPULAN}

Dari pembahasan di atas dapat disimpulkan bahwa:

1) Penilaian formatif terintegrasi dengan sangat baik pada pembelajaran microteaching di Prodi Pendidikan Matematika Universitas Qomaruddin.

2) $100 \%$ mahasiswa menyatakan setuju dan sangat setuju bahwa integrasi penilaian formatif pada pembelajaran bermanfaat dalam membantu mahasiswa mengetahui apa yang harus dilakukan untuk mencapai target pengetahuan dan keterampilan. 95,85\% mahasiswa menyatakan setuju atau sangat setuju bahwa integrasi penilaian formatif membantu mengetahui target kemampuan dan keterampilan yang harus dicapai. 93,75\% mahasiswa setuju dan sangat setuju bahwa penilaian formatif dapat memotivasi mereka untuk meningkatkan pengetahuan dan keterampilan. 93,7\% mahasiswa menyatakan setuju dan sangat setuju bahwa penilaian formatif membantu mereka mengetahui tingkat pengetahuan dan keterampilannya. $\quad 91,68 \%$ mahasiswa menyatakan setuju dan sangat setuju bahwa dengan integrasi penilaian formatif, mereka merasa menjadi pebelajar yang mandiri.

\section{DAFTAR PUSTAKA}

Arikunto, S. (2006). Prosedur penelitian suatu pendekatan praktik. Jakarta: Rineka Cipta.

Black, P. J., \& William, D. (1998). Inside the black box: raising standards through classroom assesment. London: King's College London School of Education.

Glasson, T. (2015). Improving student achievement: a practical guide to 
Illah Winiati Triyana, Integrasi Penilaian Formatif Pada Pembelajaran Microteaching

assesment for learning. South Melbourne, Vic: Cengage Learning.

Harlen, W. (2005). Teachers' summative practices and assesment for learningtensions and synergies. The Curriculum Journal. 16(2), 133-261

Sadler, D. R. (1989). Formative assesment and the design of instructional systems. Instructional Science, 18(2), 119-144.

Sukirman, D. (2012). Pembelajaran microteaching. Jakarta: Direktorat Jenderal Pendidikan islam Kementerian Agama. 